\title{
Preschool Teachers' Promotion of Self-Regulated Learning in the Classroom and Role of Contextual and Teacher-Level Factors
}

\author{
Seda Saraç,a, Betül Tarhan ${ }^{b}$
}

$\begin{array}{ll}\text { Received } & : 3 \text { September } 2020 \\ \text { Revised } & : \text { 15 October } 2020 \\ \text { Accepted } & : \text { 22 December } 2020 \\ \text { DOI } & : 10.26822 / \text { iejee.2021.192 }\end{array}$

"Corresponding Author: Seda Saraç. Bahçeşehir University, Istanbul, Turkey E-mail: seda.sarac@es.bau.edu.tr ORCID: http://orcid.org/0000-0002-4598-4029

b Betül Tarhan.

University of Georgia, Georgia, USA

E-mail: tarhan@uga.edu

ORCID: http://orcid.org/0000-0002-6339-1876

\begin{abstract}
Throughout preschool years, young children achieve important gains in terms of self-regulated learning (SRL) development. Recent research highlights the importance of the role preschool teachers in promoting SRL skills. However, several factors affect teachers' level of support in the classroom. The aim of this study was to investigate the frequency of preschool teachers' practices to promote SRL. Also, contextual (class size and children's age) and teacherlevel (year of experience and teaching self-efficacy) factors affecting their practices were investigated. The study sample consisted of 210 Turkish preschool teachers. Data were obtained via self-report measures. The participants reported that they frequently implement practices that support self-regulated learning. However, they allocated the least time on children's retrospective task reflections. Novice teachers reported more frequent SRL promotion than experienced teachers. The amount of SRL practices was affected by the class size. Teachers with more than 15 children reported less frequent SRL promotion. Also, more SRL promotion reported by teachers of older children (61-72 month olds) compared to younger children (48-60 month olds). Teacher self-efficacy was a strong predictor of teachers' SRL promotion.
\end{abstract}

\section{Keywords: \\ Early Childhood, Preschool Teachers, Self- Efficacy, \\ Self-Regulated Learning, Self-Regulation}

\section{Introduction}

The goal in educational institutions is to take a stance that will enable individuals to reach and access information on their own instead of teaching that knowledge. In this context, what needs to be done is to teach learner how to learn (Kocaman \& Osam, 2000). Teaching how to learn is to make learners self-regulated learners. Self-regulation in learning refers to the ability of an individual to manage his/her learning behaviours according to their aims (Wolters, 2003). It is a self-directed process in which learners transform their mental abilities into skills (Zimmerman, et al. 1996) and habits through a developmental process (Butler, 1998) emerging from guided practice and feedback (Paris \& Paris, 2001). In the process of self-regulated learning (SRL), learners set goals for themselves and take an active role in their learning by monitoring and controlling their cognitive processes, 
motivational levels, and behaviours (Pintrich, 2000; Zimmerman \& Schunk, 2011). Self-regulated learners can manage their learning behaviours towards their goals and have a broad repertoire of strategies that enable them to do so (Wolters, 2003).

\section{Self-Regulated Learning}

Several researchers developed models to explain SRL (Boekaerts \& Cascallar, 2006; Efklides, 2011; Winne, 1996; Zimmerman, 2000). However, these models were generally developed through studies conducted with school students and university students. Thus, current study was built on the analytic model used by Whitebread, et al. (2009) for young children and which, also, formed the theoretical basis of the T-SRL scale used in the study (Adagideli, et al., 2015). According to Whitebread, et al. (2009), SRL consists of three sub-dimensions; metacognitive knowledge, metacognitive regulation, and motivational-emotional regulation. Metacognitive knowledge pertains to the accumulated knowledge of the individual related to cognitive behaviours, goals, tasks and strategies (Flavell, 1979). There are three types of metacognitive knowledge, namely; knowledge of person, task variables, and strategy variables (Flavell, 1979; 2000). Examples of metacognitive knowledge would be knowing that mentally repeating a shopping list will be helpful in remembering or starting with the largest puzzle piece will make it easier to complete the puzzle (Marilus, et al., 2016). Metacognitive regulation refers to skills used to orchestrate cognitive behaviours while learning (Efklides, 2008; Schraw, 1998). These activities are related to individual's decisions about what, when, why, and how to act in case of a problem in monitoring and evaluating their own actions, progress, plans, and outcomes (Schraw \& Moshman, 1995). Regulatory skills can further be classified under four subcomponents; planning, monitoring, control, and evaluation (Meijer, et al. 2006; Schraw, et al., 2006). Planning, as an important dimension of behaviour regulation and cognition, includes determining the goals that will guide cognition and understanding in general and metacognitive monitoring in particular and the selection of appropriate strategies in line with these goals (Meijer, et al., 2006; Pintrich, et al., 2000; Pressley, 2000). Monitoring is an assessment of the current situation or ongoing progress of a particular cognitive activity (Dunlosky \& Metcalfe, 2009). In this way, individuals can decide, for example, whether they fully memorize the multiplication table or whether they understand the text they just read. Control refers to conscious or unconscious decisions made based on the information obtained as a result of monitoring. These decisions may cause a cognitive activity to start, continue, stop, or change the implemented strategy (Dunlosky \& Metcalfe, 2009; Nelson \& Narens, 1994). Evaluation involves judging the individual's own learning outcomes and regulatory processes with respect to task performance. Evaluating the individual's learning goals, reviewing their predictions, and combining and consolidating their cognitive gains from the task are typical evaluation activities performed during and/or after the task performance (Schraw, et al., 2006; Schraw \& Moshman, 1995). Motivational-emotional regulation is learners' monitoring and controlling of their emotions and motivational states during learning to focus attention and persist in the learning task (Boekaerts, 1999; Corno, 2001).

Promoting Self-Regulated Learning in Preschool Years The early signs of SRL skills begin in preschool years (Bronson, 2000; Larkin, 2006). Studies showed that preschool children possess metacognitive knowledge about person, task and strategy variables affecting their cognitive performance (Marilus, et al. 2016; Shamir, et al. 2009). They are also able to make plans (Adagideli \& Ader, 2017; Hendrey, et al., 2016; Jacob, et al, 2019), monitor (Marazita \& Merrima, 2004) and control their own learning processes (Dörr \& Perels, 2019a; Jacob, et al, 2019; Robson, 2010) and evaluate and reflect on their learning (Perry \& VandeKamp, 2000; Zelazo, 2015). Young children also can regulate their emotions and motivations to initiate, plan and persist on learning tasks (Whitebread, et al., 2005).,

Early childhood education has a very important role in the development of children. The first years when children enter into educational system are also the years when their attitudes toward education and perception of self-efficacy begin to develop (Whitebread, 2000). Mistakes made in instructional processes during these years cause children to develop ineffective and undesirable-even harmfullearning habits and behaviours (Dignath \& Büttner, 2008; Dignath, et al., 2008; Perels \& Otto, 2009; Perry, et al., 2004), and these habits and behaviours have negative effects on children's future academic achievement. In the same vein, Larkin (2009) attaches importance to promoting SRL skills that are required to cope with the challenging tasks for achieving in school. According to Baron (2015), even minor selfregulatory skill differences among preschool children in this period emerge as large differences in a child's academic success over time. Therefore, early SRL support has a preventive aspect in the long term (Venitz \& Perels, 2019a).

Several intervention studies reported gains in young children's SRL when supported by the teachers (Dörr \& Perels, 2019b; Perels, et al. 2008;). Findings mostly obtained from observational studies revealed that in the learning environments where; activities were child-centred (Stipek, et al. 1995), complex tasks were presented (Perry \& Vandekamp, 2000; Whitebread, 
et al. 2009), children were allowed to choose the difficulty level of the tasks (Perry \& Vandekamp, 2008), the assessments were non-threatening (Perry \& Vandekamp, 2000), opportunities for peer and small group work activities were presented, child-initiated, independent activities were supported (Nietzel \& Connor, 2017; Whitebread, et al., 2009), children were encouraged to articulate their thinking processes (Whitebread \& Coltman, 2010) and a warm teacherchild relationship were established (Perry, 1998; Perry \& Vandekamp, 2008; Whitebread \& Coltman, 2010).

As the above-mentioned studies revealed, the way teaching-learning processes are designed is key to the development of children's SRL skills. In this regard, the teacher, as the regulator of learning environment and teaching-learning processes, has a primary role (Venitz \& Perels, 2019b). Instead of the teachercentred, teacher-directed teaching and learning environments in which teachers assume the control, teachers should create such environments in which children feel they are in control and allowed to make decisions about their own learning (Kistner, et al., 2010; Perry \& Vandekamp, 2009).

\section{Teacher-Level Factors Affecting Teachers' Promotion of Self-Regulated Learning}

Teachers play a key role in promoting self-regulation skills (Peeters, et al., 206). In studies with primary school teachers, teacher-level variables appeared to be the most important factors affecting teachers' promotion of SRL in their classrooms (Lombaerts, et al. 2009; Thomas, et al., 2020). Teachers' beliefs and teaching experience were the prominent factors in SRL practices (Lombaerts, et al., 2007, Moos \& Ringdal, 2012).

There are several studies examining the level of primary and secondary school teachers' support of SRL and the factors affecting their level of support. Among the factors that affect teachers' support of SRL in primary schools, one particular teacher characteristic, namely teachers' self-efficacy beliefs, was consistently found to be a significant factor affecting teachers' practices that promote SRL (Chatzistamatiou, et al. 2013; Dignathvan Ewijk, 2016; Lombaerts, et al., 2009; Vandevelde, et al., 2013; Tanriseven, 2013). Self-efficacy belief is the self-judgment of individuals about their capacity to plan and accomplish the required activities for performance in a specific subject (Bandura, 1997). The perception of teachers' self-efficacy is their self-belief in establishing a successful learning environment (Goddard, et al., 2004). For Bandura (1993), teacher's beliefs in their self-efficacy in enhancing learning and learner-motivation in the classroom affect the characteristics of the learning environment they create in the classroom, and, thus, the learners' achievement (Bandura, 1993). Studies showed that teachers who perceive themselves to be self-effective make more effort for teaching, become more open to new ideas that can contribute to their students' learning, and leave more room for innovative practices (TschannenMoran, et al., 1998). Fantuzzo, et al. (2012) showed that the preschool teachers with higher self-efficacy beliefs spend more time on cognitive and socio-affective learning in their classrooms. Furthermore, Perren, et al. (2017) concluded that preschool teachers with higher self-efficacy beliefs are more successful in creating child-centred learning environments that effectively support children's learning and development by taking into account the children's individual and developmental levels. As for SRL, no studies have investigated the effect of preschool teachers' selfefficacy beliefs on their SRL practices so far.

Another important teacher-level variable that may affect teachers' promotion of SRL may be the seniority of the teachers. As mentioned above, less controlling environments are recommended for the development of SRL of preschool children, According to Martin, et al. (2006) experienced teachers were more competent in establishing classroom routines than novice teachers and they display less controlling behaviours in the classroom. Zembat and Yllmaz (2018) investigated the effect of teacher seniority on preschool teacher practices promoting SRL in the classroom and consistent with Martin, et al. (2006), teachers with more than 11 years of teaching experiences reported more frequent use of SRL practices than teachers' with less experience.

\section{Contextual Factors Affecting Teachers' Promotion of Self-Regulated Learning}

Researchers call for studies to identify the contextual factors that cause differences in teachers' SRL support practices (Muijs, et al., 2014). One contextual factor that may impact teachers' self-regulated support is the class size. Although there are no studies on whether the classroom size affects teachers' SRL support in early childhood classrooms, there are studies showing that the class size affects the quality of teaching. In their literature review Francis, \& Barnett (2019) review pointed out that classroom size was important in early childhood education and that reducing the number of children by 5 had a positive effect on the quality of teaching and increases the success of children in the classroom. Similary, Le, et al. (2015) study evidenced a threshold at about 15 children per classroom. When the number of students exceeded over 15, it decreased the teacher-student interaction and thus the observed quality of teaching. 
Another contextual factor, age of the children, may affect teachers' SRL practices in the early years. No study investigating whether there is a difference between age groups in terms of teachers' SRL support in the preschool period was found. However, it can be expected that there will be more support for SRL in pre-primary group compared to younger age groups, as pre-primary curriculum concentrates more on academic skills (MoNE, 2013).

\section{Purpose of the Study}

Although studies on self-regulated learning are not new, research in this field is mostly conducted at primary, secondary, and tertiary levels. Studies on preschool children started in the 2000s only. This delay is largely due to a common assumption that metacognition as the cognitive dimension of SRL is only beginning to develop at around the age of 8-10 (Whitebread, et al., 2009). However, studies using learning tasks that children frequently encounter in daily life and studies conducted by observing children in their natural environment instead of relying on their verbal skills proved earlier emergence of SRL skills than expected (e.g., Annevirta \& Vauras, 2006; Larkin, 2006; Perels, et al. 2008; Perry, 1998; Perry \& VandeKamp, 2000; Robson, 2010; Whitebread \& Coltman, 2010). Although all these findings paved the way for the studies on how to develop these skills, literature on to what extent preschool teachers' support SRL in their classrooms and the factors that affect their support are scarce. Uncovering the factors that affect the SRL support of preschool teachers can shed light on eliminating preventive factors and determining when and how teachers can be supported during pre-service and in-service teacher education and training. To fill this gap, this study aimed to investigate preschool teachers' practices in promoting SRL in their classrooms and the factors affecting their promotion. Following the recommendations of Lombaerts, et al. (2009) this study focused on teacher-level and contextual factors. As for the teacher level factors, the study concentrates on the teachers' year of experience and teaching self-efficacy beliefs. The age of the children in the classroom and the number of children were scrutinized as the contextual factors.

\section{Context of the Study}

Preschool education is not compulsory in Turkey. Early childhood education and care (ECEC) services are provided and administered under the Ministry of National Education (MoNE) or Ministry of Family and Social Policies (MoFSP). Institutions serving children up to three years of age operate under the MoFSP, while institutions serving children aged 3-5 operate under the MoNE. MoNE affiliated preschools provide educational services for 36-68 months old children (MoNE, 2014).
As Turkey adopted a centralized educational system, the MoNE determines the preschool curriculum. The preschool education curriculum, last updated in 2013, was developed to ensure healthy development of children through rich learning experiences. The curriculum is versatile with supportive and preventive dimensions. The curriculum aims to support all developmental areas as well as preparing them for primary education and to prevent deficiencies that can be seen in all development areas. (MoNE, 2013).

From the perspective of promoting SRL, there is no clear reference in the curriculum. However, several principles on which the curriculum is based, point to the provision of learning environments that enable the development of SRL skills. It was clearly stated in the curriculum documents that the program is prepared with a child-centred approach and all practices should be strictly performed within this framework Also, the main principles underlying the curriculum puts emphasis on allowing children to learn through experiments, arranging play-based activities, allocating as much time as possible to children's independent play, allocating balanced time for individual, small group, and whole class activities. In addition, the curriculum highlights the importance of building a sensitive, warm and consistent relationship between teacher and child in order for children to realize their potential. (MoNE, 2013) which aligns with findings of Perry and Vandekamp (2008) and Whitebread and Coltman (2010) regarding environments that supported SRL development of young children.

The MoNE (2013) curriculum was organized around three age groups: 36-48 months, 48-60 months, and 61-72 months. Thus, typically, in all the MoNE-affiliated kindergartens, children are divided into classes according to these age groups and receive education within the curricular aims determined for that age group (MoNE, 2014).

According to MoNE (2014), it is essential that the number of children in a group should not be less than 10 and more than 20. If the number of children is higher than this number, a second group should be formed. However, in some cases, due to lack of enough number of teachers, there can be more than 20 children in one class.

\section{Research Questions of the Study}

There are four research questions in this study:

1. Do preschool teachers report using practices that support SRL?

2. Do the frequency of teachers' support practices vary according to sub-dimensions of SRL? 
3. Do contextual factors (class size and children's age) affect Turkish preschool teachers' promotion of SRL?

4. Do teacher-level factors (years of experience and self-efficacy beliefs) affect Turkish preschool teachers' promotion of SRL?

\section{Method}

\section{Subjects of the Study}

The participants of the study were preschool teachers from MoNE-affliated preschools in Istanbul, Turkey $(N=$ 210). Participation in the study was voluntary. Data obtained via anonymous questionnaires. Informed consent was received with yes / no question before filling the questionnaire. It is stated in the Informed Consent that they can withdraw any time. All the participating teachers were female (100\%). The participants' ages ranged between 20 years and over 40 years. In order to become a preschool teacher and to work in MoNE-affliated preschools in Turkey, it is obligatory to have a 4-year bachelor's degree from Faculty of Preschool Teacher Education Candidates take theoretical and practical courses during their four-year undergraduate education. All teacher education programs implement the same curriculum developed by the Higher Education Council. Thus, all participating teachers have at least BA degree in preschool teaching. Some teachers, also, hold an MA degree in preschool teaching (4.8\%). All teachers stated that they did not receive formal or informal training in SRL. Teachers either work at kindergarten (4- to 5-year-olds) or pre-primary classes (5- to 6-yearolds). Based on the results of Bivona's (2002) and
Martin, et al. (2006) studies, the teachers were divided into two groups according to the number of years they teach, as between 0-10 years (novice) and over 10 years (experienced). Also, in line with the findings of Lee, et al. (2015) and Francis and Barnett (2019) studies class sizes were investigated in three groups as 0-15, 16-20 and 21 and above. Descriptive characteristics of the participant teachers are presented in Table 1.

\section{Measurement Tools}

The present study used three tools to collect data.

\section{Personal information form}

A personal information form compiled by the researchers was used to collect data on the participants' age, gender, years of experience, the type of institution they work for, the age group they teach, class size.

\section{Teachers' Practices to Promote Self-Regulated Learning Scale (T-SRL)}

The T-SRL is a self-report scale developed by Adagideli, et al. (2015) to assess the extent to which preschool teachers promote SRL. The 21-item scale consists of five subscales; namely, metacognitive knowledge of the person (three items), metacognitive knowledge of task and strategy (four items), metacognitive regulation during the task (six items), metacognitive regulation after the task (three items) and emotional and motivational regulation (five items). Table 2 shows sample items from each subscale.

Table 1

Participant Preschool Teachers' Descriptive Characteristics

\begin{tabular}{|c|c|c|c|}
\hline Groups & $n$ & $f$ & $\%$ \\
\hline \multirow{2}{*}{ Years of experience } & Up to 10 years & 145 & 69.0 \\
\hline & 11 years and above & 65 & 31.0 \\
\hline \multirow{3}{*}{ Class size } & Up to 15 children (small) & 55 & 26.2 \\
\hline & 16-20 children (medium) & 105 & 50.0 \\
\hline & 21 children and above (large) & 50 & 23.8 \\
\hline \multirow{2}{*}{ Age of children } & Kindergarten (48-60-month-olds) & 71 & 33.8 \\
\hline & Pre-primary (61-72-month-olds) & 139 & 66.2 \\
\hline \multirow{2}{*}{ School type } & Public & 69 & 32.9 \\
\hline & Private & 141 & 67.1 \\
\hline
\end{tabular}

Table 2

T-SRL Subscale Sample Items

\begin{tabular}{ll}
\hline T-SRL subscale & Sample items \\
\hline Metacognitive knowledge of person & I provide opportunities for my children to be aware of how they learn. \\
\hline Metacognitive knowledge of task and strategy & I draw my children's attention to various strategies that they can use for classroom tasks. \\
\hline Metacognitive regulation during task & I let my children make decisions about how to work \\
\hline Metacognitive regulation after task & I teach my children how to evaluate their learning \\
\hline
\end{tabular}


The items were formulated into statements so teachers could respond on a four-point scale $(0=$ never; $3=$ always). The internal reliability of the total scale for the original study was .91. The internal reliability of the subscales of the original study were .72 for the metacognitive knowledge of person, .79 for the metacognitive knowledge of task and strategy, 81 for the metacognitive regulation during task, .75 for the metacognitive regulation after task and .84 for the emotional and motivational regulation. For the current study internal reliability for the subscales were .84, .89, $.86, .84$ and .82 , respectively. The internal reliability of the total scale for the current study was .94 .

\section{Preschool Teachers' Self -Efficacy Beliefs Scale}

The "Single-Dimension Self-Efficacy Beliefs Scale for Preschool Teachers" developed by Tepe and Demir (2012) was used to measure the preschool teachers' self-efficacy beliefs about teaching. The scale, consisting of 37 items, was designed as a five-point Likert scale ( $\mathrm{O}=$ Not at all; $4=$ Completely). The scale includes items for the teaching-learning process (e.g. I can ensure the active participation of my students in the learning process), and communication skills (e.g. I can use body language (posture, gestures, eye contact, etc. effectively), family participation (e.g. I can encourage families to participate in school and classroom activities.), planning (e.g. I can plan transitions between activities in a way that does not disturb the flow of the lesson), designing learning environments (e.g. I can organize the learning environment to support my students' creativity., and classroom management (e.g. I can come up with solutions for negative student behaviour), and it is used as single-dimensional with a single total score. The maximum score obtained from the scale was 148 , while the minimum score was 0 . Higher scores indicate higher teaching self-efficacy. The internal consistency for the original study for the total scale was .97, while the internal reliability of the scale for the current study was 95 .

\section{Results}

The study investigated preschool teachers' practices in promoting SRL in their classrooms and the factors affecting their promotion. The findings regarding research questions are presented below under their respective headings.

\section{Do preschool teachers report using practices that support SRL?}

To find out whether preschool teachers promote SRL in the classroom, first, calculations were made for the minimum and the maximum values, arithmetic means, and standard deviation values for each subdimension in the T-SRL. These values are presented in Table 3. As can be seen in Table 1, teachers reported that they frequently included practices that support all sub-dimensions of SRL in their classroom.

\section{Do the frequency of teachers' support practices vary according to different sub- dimensions of SRL?}

To find out whether the frequency of support practices vary according to different sub-dimensions of $S R L$, one-way within-subjects ANOVA was conducted. No outliers have been observed, and data were normally distributed at each time point, as assessed by box plot and the Shapiro-Wilk test ( $p>$.05). The findings of Mauchly's test of sphericity revealed that the assumption of sphericity was violated, $\chi^{2}(2)=113$, 074, $p=.000$, and therefore, a Greenhouse-Geisser correction was used. One-way within-subjects ANOVA with a Greenhouse-Geisser correction showed a statistically significant difference between at least two means $(F[3.127,653.461]=13.267, p=.000)$. Post hoc tests using the Bonferroni correction revealed that only the mean scores for Metacognitive Regulation After Task $(M=2.504, S D=.535)$ differed significantly from Metacognitive Knowledge of Person $(M=2.660$, $S D=.437)$, Metacognitive Knowledge of Task and Strategy $(M=2.671, S D=.416)$, Metacognitive Regulation

Table 3

Descriptive Statistics of the T-SRL Subscales

\begin{tabular}{|c|c|c|c|c|c|}
\hline Scale & $N$ & Min. & Max. & $M$ & Sd. \\
\hline Metacognitive knowledge of person & 210 & 1.00 & 3.00 & 2.66 & .44 \\
\hline Metacognitive knowledge of task and strategy & 210 & 1.75 & 3.00 & 2.67 & .42 \\
\hline Metacognitive regulation during task & 210 & 1.17 & 3.00 & 2.66 & .42 \\
\hline Metacognitive regulation after task & 210 & 1.00 & 3.00 & 2.50 & .40 \\
\hline Emotional and motivational regulation & 210 & 1.80 & 3.00 & 2.60 & .42 \\
\hline T-SRL Total & 210 & 1.71 & 3.00 & 2.62 & .36 \\
\hline
\end{tabular}


During Task $(M=2.658, S D=.419)$, and Emotional and Motivational Regulation $(M=2.598, S D=.399)$. In other words, preschool teachers reported to allocate the least time on children's retrospective task reflections $(p<.001)$.

Do contextual factors (class size and children's age) affect preschool teachers' promotion of SRL?

A one-way ANOVA was used to determine whether teachers' SRL practices differ by the class size. Table 4 shows ANOVA results.

One- way ANOVA result with the T-SRL total score showed that the frequency of SRL support varies with the class size. According to Fisher's LSD post hoc results, teachers of large classes reported significantly less SRL support practices in their classes compared to small and medium classes ( $p<.05)$. When comparisons were made for sub-dimensions, the results showed that, apart from Metacognitive Knowledge of Person, class size is an important determinant of teachers' SRL practices. Fisher's LSD post hoc analyses revealed that there were no statistically significant differences between small (up to 15 children) and medium (16 to 20 children) classes in terms of teachers' support for Metacognitive Knowledge of Task and Strategy, Metacognitive Regulation During Task and Emotional and Motivational Regulation. However, SRL support for these sub-dimensions significantly decreased for large classes (21 and above children) when compared to small and medium classes $(p<.05)$. Only for Metacognitive Regulation After Task, teachers of medium classes reported more frequent use of practices compared to small and large classes $(p<.05)$.

Considering the age group of the children taught by teachers, independent samples t-tests showed no difference among frequency of support for Metacognitive Knowledge of Task and Strategy, Metacognitive Regulation During Task, and Emotional and Motivational Regulation. However, statistically significant differences observed among Metacognitive Knowledge of Person for the kindergarten group ( $M=$ $2.568, S D=0.427)$ and the pre-primary group $(M D=2.707$, $S D=.437,+[208]=-2.202, p<.05$ and in Metacognitive Regulation After Task for the kindergarten group ( $M=$ $2.399, S D=0.545)$ and the pre-primary group $(M D=2.559$, $S D=.524),+[208]=-2.062, p<.05$. Pre-primary teachers reported more frequent utilization of practices to support Metacognitive Knowledge of Person and Metacognitive Regulation After Task.

Do teacher-level factors (years of experience and selfefficacy beliefs) affect preschool teachers' promotion of SRL?

Independent samples t-tests were used to examine whether preschool teachers' years of experience affect their practices to support SRL. Analysis with the T-SRL total score showed that the frequency of SRL support did not differ according to the teachers' year

\section{Table 4}

Results of one-way ANOVA for class size

\begin{tabular}{lccccccc}
\hline Measure & \multicolumn{2}{c}{$\begin{array}{c}\text { Small classes } \\
(n=55)\end{array}$} & \multicolumn{2}{c}{$\begin{array}{c}\text { Medium classes } \\
(n=105)\end{array}$} & $\begin{array}{c}\text { Large classes } \\
(n=50)\end{array}$ & $\begin{array}{c}F \\
(2,207)\end{array}$ \\
\hline Metacognitive knowledge of person & $M$ & $S D$ & $M$ & SD & M & SD \\
\hline Metacognitive knowledge of task and strategy & 2.66 & .45 & 2.71 & .43 & 2.55 & .42 & 2.147 \\
\hline Metacognitive regulation during task & 2.75 & .38 & 2.69 & .41 & 2.55 & .43 & $3.490^{*}$ \\
\hline Metacognitive regulation after task & 2.69 & .41 & 2.71 & .37 & 2.52 & .43 & $4.257^{*}$ \\
\hline Emotional and motivational regulation & 2.48 & .50 & 2.58 & .51 & 2.35 & .60 & $3.265^{*}$ \\
\hline T-SRL Total & 2.65 & .41 & 2.63 & .40 & 2.47 & .44 & $4.257^{*}$ \\
\hline${ }^{*}$ c $<05$ & 2.65 & .36 & 2.67 & .35 & 2.49 & .36 & $4.504^{*}$ \\
\hline
\end{tabular}

Table 5

Results of simple linear regression analyses on predictive effect of self-efficacy beliefs on SRL practices

\begin{tabular}{|c|c|c|c|c|c|c|}
\hline & $R$ & $R^{2}$ & $F$ & Std. E & $\beta$ & $\dagger(208)$ \\
\hline Metacognitive Knowledge of Person & .483 & .234 & 63.396 & .002 & .483 & $7.962^{*}$ \\
\hline Metacognitive Knowledge of Task and Strategy & .452 & .204 & 53.435 & .002 & .452 & $7.310^{*}$ \\
\hline Metacognitive Regulation During Task & .529 & .280 & 80.974 & .002 & .529 & $8.999^{*}$ \\
\hline Metacognitive Regulation After Task & .561 & .315 & 95.549 & .002 & .561 & $9.775^{*}$ \\
\hline Emotional and Motivational Regulation & .593 & .352 & 112.997 & .002 & .593 & $10.630^{*}$ \\
\hline T-SRL Total & .628 & .395 & 135.550 & .002 & .628 & $11.643^{*}$ \\
\hline
\end{tabular}


of experience. When comparisons are made for subdimensions, the results revealed that the frequency of practices to support Metacognitive Knowledge of Person, Metacognitive Knowledge of Task and Strategy, and Metacognitive Regulation After Task does not differ by the teachers' years of experience. However, novice teachers (0-10 years) $(M D=2.699, S D=$ .353) support Metacognitive Regulation During Task more than teachers with over 11 years of experience $(M D=2.567, S D=.478),+[96.535]=2.000, p<.05)$.

Simple linear regressions were calculated to predict the preschool teachers' practices that promote selfregulated learning based on teachers' self-efficacy beliefs. Table 5 shows regression results. The results showed that teachers' self-efficacy scores significantly predicted total SRL practices as well as practices on every sub-dimension. This suggests that $40 \%$ of the variation in the T-SRL total scores is explained by teachers' self-efficacy beliefs. For the sub-dimensions, the amount of variance explained varies between $20 \%$ and $35 \%$.

\section{Discussion}

Important gains in self-regulated learning skills emerge in the early childhood years. In this context, it becomes even more important that preschool teachers create environments that support SRL. Promoting SRL can be possible by creating environments in which children can practice their SRL skills. In this study, the frequency of teachers' practices supporting SRL in the classroom was examined based on the teachers' self-reports. Preschool teachers reported that they frequently implement practices that support children's SRL. The participant teachers had no formal or informal training on how to support SRL. It seems that although teachers do not know or name the strategies they have developed, they intuitively understand their importance and even implement them in their classrooms. However, among all the sub-dimensions of $\mathrm{SRL}$, teachers devote the least time to self-evaluation and peer-evaluation activities. With peer- and selfevaluation practices, students are encouraged to participate in the evaluation process, which is an important part of the self-reflection phase of selfregulation (Zimmerman, 2008). Several researchers highlighted the importance of self-evaluation and peer-evaluation as part of practices that support SRL (Dignath, et al., 2008; Panadero \& Alonso-Tapia, 2013; Panadero, et al. 2017; Panadero \& Romero, 2014). Consistent with the results of the current study, teachers do not always prefer active involvement of the students in the evaluation (Jonsson, et al., 2015; Panadero, et al., 2016; Spruce \& Bol, 2015). Studies with the teachers of older students showed that teachers were concerned about their students' maturity to be objective and truthful in self and peer evaluation (e.g.,
Noonan \& Duncan, 2005). Given that self-evaluation and peer-evaluation activities have an important role in supporting SRL, teachers should be informed about the importance of self- and peer evaluation and supported on how to engage children in evaluations activities in the classroom.

In this study two contextual factors (class size and age of children) were investigated. In terms of the age group of the children (kindergarten vs. pre-primary), teachers of both groups reported that they frequently support for children so that they get to know task types, realize the strategies to be used according to the task type, and monitor and control their cognition, emotions, attention, and motivation. However, the teachers working with older children, i.e. pre-primary reported providing more frequent support for children to acquire information about their cognitive processes (metacognitive knowledge of person) and evaluate their performance (metacognitive regulation after task). Considering that the pre-primary children will start primary school the following year, it's plausible that the teachers are more academic-oriented and, therefore, more concerned with developing children's metacognitive knowledge and evaluation skills.

As for the class size, the number of the students in a class does affect the frequency of teachers' reported support for the students. It seems that having more than 20 students hinders teachers' SRL support. For the effective promotion of SRL skills in preschool independent work, peer work and collaborative work emerge as the most prominent support structures in the classroom (liskala, et al., 2004; Perry, et al, 2002; Whitebread at al., 2007). A recent meta-analysis in early childhood education highlighted the importance of small class sizes (Bowne, et al., 2017). According to Almulla (2015) teachers have difficulties in applying effective teaching strategies in large-size classrooms, and they prefer to use teacher-centred teaching strategies instead of learner-centred approaches. Similarly, Blatchford, et al., (2005) posited that teachers in large classes were likely to use whole class teaching, teacher-directed activities, whereas in smaller classes teachers were more prone to utilize group work and were able to give attention and support to each student individually. So, if the aim is to develop selfregulated learners, all necessary precautions should be taken in order for the class sizes to be below 20.

Comparing experienced and novice teachers, the results showed that only the frequency of support on Metacognitive Regulation During Task dimension differs between novice and experienced teachers, i.e. novice teachers appeared to provide students with more information and support to keep track of their learning and ask for help, which can be associated with newly-graduated teachers' more familiarity with 
the new perspectives on learner-centeredness than their experienced colleagues. This result is consistent with Wilcox-Herzog's study (2002), where more experienced preschool teachers were less sensitive to children's developmental levels which is the basis for promoting SRL in the classrooms. Similarly, Klug, et al., (2015) and Peeters, et al., (2015) reported that more experienced teachers were less likely to support SRL. However, the findings are inconsistent with Zembat and Yilmaz (2018) study. In their study, they used the same scale, i.e. T-SRL, with the current study and they found a significant difference in favour of those teachers with over 11 years of experience on total T-SRL scores. This inconsistency needs further investigation. With regard to the relationship between the teachers' support for SRL and their self-efficacy beliefs, the level of self-efficacy belief can account for teachers' support to a great extent. Various studies showed that in order to support SRL in the classroom, teachers needed to allow their students to experiment through these skills with more learner-centred activities (Perry \& Vandekamp, 2000; Stipek, et al. 1995; Whitebread, et al., 2009). It seems that the higher the teachers' self-efficacy beliefs, the braver they get, and the more room is provided for the activities initiated by the children. The results of the present study are also consistent with the results of the studies conducted with the teachers of older age groups (e.g., Lombaerts, et al., 2009; Tanriseven, 2013). This result posits that teachers' self-efficacy should be developed by equipping teachers with learner-centred pedagogies through pre-service and in-service training.

\section{Conclusions, Limitations, and Directions for Future Studies}

Self-regulated learning skills are considered among the basic requisites of both life-long learning and academic achievement. It is extremely important that teachers support students in taking the responsibility for their own learning, hence help them in becoming selfregulated learners. This study shows that even though preschool teachers do not receive formal training in SRL and how to support it, they intuitively feel the need to support their students' SRL skills. Nevertheless, it is necessary to take this as an educational policy instead of leaving the issue to teachers' instincts or limiting it within rather few things that they learn at school.

This study is important, as this is one of the first studies to examine the SRL practices of preschool teachers according to the sub-dimensions of SRL and try to reveal the contextual and teacher-level factors that affect these practices. However, this study was based on teachers' self-reports. The results obtained should be considered accordingly. In fact, there are observational studies from the Turkish preschool context showing that teachers allocate very limited time for children's independent work that is known to support SRL. For instance, Gol-Guven (2009) studied ECEC classrooms in Turkey to identify quality indicators. She observed that children often engage in whole group, teacher-led activities, and spend a little time for the small group or individual activities. In a more recent study by Varol (2013), it has been observed that preschool teachers generally spend time on teacherled large group activities. The time allocated for small group activities, which is extremely important for the development of SRL, is only $2 \%$. It has been observed that only $14 \%$ of the class time was allocated to play, which also has an important role in the development of SRL. Hence, observations of preschool teachers' actual practices in classroom contexts should be examined by future studies.

\section{References}

Adagideli, F. H., \& Ader, E. (2017). Matematiksel problem çözme etkinliklerinde küçük çocukların üstbilişsel düzenleme becerilerinin incelenmesi. Journal of Kirsehir Education Faculty, 18(2). 193-211.

Adagideli, F. H., Saraç, S. \& Ader, E. (2015). Assessing preschool teachers' practices to promote selfregulated learning. International Electronic Journal of Elementary Education, 7(3), 423-440.

Almulla, M. A. (2015). An Investigation of teachers' perceptions of the effects of class size on teaching. International Education Studies, 8(12), 33-42. https://doi.org/10.5539/ies.v8n12p33.

Annevirta, T. \& Vauras, M. (2006). Developmental changes of metacognitive skill in elementary school children. The Journal of Experimental Education, 74(3), 195-226. https://doi.org/10.3200/ JEXE.74.3.195-226

Bandura, A. (1993). Perceived self-efficacy in cognitive development and functioning. Educational Psychologist, 28(2), 117-148. https://doi.org/10.1207/ s15326985ep2802_3.

Bandura, A. (1997). Self-efficacy: The exercise of control. W. H. Freeman.

Baron, R. J. (2015). Professional self-regulation in a changing world: old problems need new approaches. JAMA, 313(18), 1807-1808. https:// doi.org/10.1001/jama.2015.4060. 
Blatchford, P., Bassett, P., \& Brown, P. (2005). Teachers' and pupils' behaviour in large and small classes: A systematic observation study of pupils aged 10 and 11 years. Journal of Educational Psychology, 97(3), 454-467. https://doi.org/10.1037/00220663.97.3.454.

Boekaerts, M. (1999). Self-regulated learning: where we are today. International Journal of Educational Research, 31, 445-457. https://doi.org/10.1016/ s0883-0355(99)00014-2.

Boekaerts, M.\& Cascallar, E. (2006). How far have we moved toward the integration of theory and practice in self-regulation? Educational Psychology Review, 18, 199-210. https://doi. org/10.1007/s10648-006-9013-4

Bowne, J. B., Magnuson, K. A., Schindler, H. S., Duncan, G. J., \& Yoshikawa, H. (2017). A meta-analysis of class sizes and ratios in early childhood education programs: Are thresholds of quality associated with greater impacts on cognitive, achievement, and socioemotional outcomes? Educational Evaluation and Policy Analysis, 39(3), 407-428. https://doi. org/10.3102/0162373716689489.

Butler, D. L. (1998). The strategic content learning approach to promoting self-regulated learning: A report of three studies. Journal of Educational Psychology, 90(4), 682. https://doi. org/10.1037/0022-0663.90.4.682.

Butler, D. L. (2002). Qualitative approaches to investigating self-regulated learning: Contributions and challenges. Educational Psychologist, 37(1), 59-63. https://doi. org/10.1207/00461520252828564.

Chatzistamatiou, M., Dermitzaki, I. \& Bagiatis, V. (2013). Self-regulatory teaching in mathematics: relations to teachers' motivation, affect and professional commitment. European Journal of Psychology of Education, 29(2), 295-310. https:// doi.org/10.1007/s10212-013-0199-9

Corno, L. (2001). Volitional aspects of self-regulated learning. In B. J. Zimmerman \& D. H. Schunk (Eds.), Self-Regulated Learning and Academic Achievement: Theoretical Perspectives, 191-225. Routledge.

Dignath-van Ewijk, C. (2016). Which components of teacher competence determine whether teachers enhance self-regulated learning? Predicting teachers' self-reported promotion of self-regulated learning by means of teacher beliefs, knowledge, and self-efficacy. Frontline Learning Research, 4(5), 83-105. https://doi. org/10.14786/fIr.v4i5.247.
Dignath, C. \& Büttner, G. (2008). Components of fostering self-regulated learning among students. A meta-analysis on intervention studies at primary and secondary school level. Metacognition and Learning, 3(3), 231-264. https://doi.org/10.1007/s11409-008-9029-x.

Dignath, C., Büttner, G. \& Langfeldt, H. (2008). How can primary school students learn SRL strategies most effectively? A meta-analysis on selfregulation training programmes. Educational Research Review, 3(2), 101-129. https://doi. org/10.1016/j.edurev.2008.02.003.

Dörr, L., \& Perels, F. (2019a). Improving metacognitive abilities as an important prerequisite for selfregulated learning in preschool children. International Electronic Journal of Elementary Education, 11(5), 449-459. https://doi.org/26822/ iejee.2019553341.

Dörr, L. \& Perels, F. (2019b). Improving young children's self-regulated learning using a combination of direct and indirect interventions. Early Child Development and Care, 1-13. https://doi.org/10. 1080/03004430.2019.1595608.

Dunlosky, J., \& Metcalfe, J. (2009). Metacognition. Sage Publications.

Efklides, A. (2008). Metacognition. Defining its facets and levels of functioning in relation to self-regulation and co-regulation. European Psychologist, 13, 277-287. https://doi. org/10.1027/1016-9040.13.4.277.

Efklides, A. (2011). Interactions of metacognition with motivation and affect in self-regulated learning: the MASRL model. Educational Psychology, 46, 6-25. https://doi.org/10.1080/00461520.2011.5386 45.

Fantuzzo, J., Perlman, S., Sproul, F., Minney, A., Perry, M. A., \& Li, F. (2012). Making visible teacher reports of their teaching experiences: The early childhood teacher experiences scale. Psychology in the Schools, 49(2), 194-205. https://doi.org/10.1002/ pits.20623.

Francis, J., \& Barnett, W. S. (2019). Relating preschool class size to classroom quality and student achievement. Early Childhood Research Quarterly, 49, 49-58. https://doi.org/10.1016/j. ecresq.2019.05.002

Flavell, J. H. (1979). Metacognition and cognitive monitoring: A new area of cognitivedevelopmental inquiry. American Psychologist, 34(10), 906-911. doi:10.1037/0003-066X.34.10.906. 
Flavell,J.H.(2000). Developmentofchildren'sknowledge about the mental world. International Journal of Behavioral Development, 24(1), 15-23. https:// doi.org/10.1080/016502500383421.

Goddard, R. D., Hoy, W. K., \& Woolfolk-Hoy, A. (2004). Collective efficacy beliefs: Theoretical developments, empirical evidence, and future directions. Educational Researchers, 33(3), 3-13. https://doi.org/10.3102/0013189X033003003.

Gol-Guven, M. (2009). Evaluation of the quality of early childhood classrooms in Turkey. Early Child Development and Care, 179(4), 437-451. https:// doi.org/10.1080/03004430701217639.

Hendry, A., Jones, E. J., \& Charman, T. (2016). Executive function in the first three years of life: Precursors, predictors and patterns. Developmental Review, 42, 1-33. https://doi.org/10.1016/j.dr.2016.06.005.

Jacob, L., Dörrenbächer, S., \& Perels, F. (2019). A Pilot study of the Online Assessment of SelfRegulated Learning in Preschool Children. International Electronic Journal of Elementary Education, 12(2), 115-126. https://doi.org/10.26822/ iejee.2019257655.

Kistner, S., Rakoczy, K., Otto, B., Dignath-van Ewijk, C. Büttner, G., \& Klieme, E. (2010). Promotion of selfregulated learning in classrooms: Investigating frequency, quality, and consequences for student performance. Metacognition and Learning, 5(2), 157-171. https://doi.org/10.1007/ s11409-010-9055-3.

Kocaman, A. ve Osam N. (2000). Uygulamalı dilbilimyabancı dil öğretimi terimleri sözlüğü. Hiti† Yayınevi.

Labuhn, A. S., Zimerman, B. J. \& Hasselhorn, M. (2010). Enhancing students' self-regulation and mathematics performance: The influence of feedback and self-evaluative standards. Metacognition and Learning, 5(2), 173-194. https://doi.org/10.1007/s11409-010-9056-2.

Larkin, S. (2006). Collaborative group work and individual development of metacognition in the early years. Research in Science Education, 36, 7-27. https://doi.org/10.1007/s11165-006-8147-1.

Larkin, S. (2009). Metacognition in young children. Routledge.

Le, V. N., Schaack, D. D., \& Setodji, C. M. (2015). Identifying baseline and ceiling thresholds within the Qualistar early learning quality rating and improvement system. Early Childhood Research Quarterly, 30, 215-226. https://doi.org/10.1016/j. ecresq.2014.03.003.
Lombaerts, K., Engels, N. \& Vanderfaeillie, J. (2007). Exploring teachers' actions to promote selfregulated learning practices in primary school. Australian Educational and Developmental Psychologist, 24(1) (2007), 4-24. https://doi. org/10.3200/joer.102.3.163-174.

Lombaerts, K., Engels, N., \& Braak, J. (2009). Determinants of teachers' recognitions of self-regulated learning practices in elementary education. The Journal of Educational Research, 102(3), 163174. https://doi.org/10.3200/JOER.102.3.163-174.

Marazita, J. M., \& Merriman, W. E. (2004). Young children's judgment of whether they know names for objects: The metalinguistic ability it reflects and the processes it involves. Journal of Memory and Language, 51, 458-472. https://doi. org/10.1016/j.jml.2004.06.008.

Martin, N., Yin, Z., \& Mayall, H. (2006, February). Classroom management training, teaching experience and gender: Do these variables impact teachers' attitudes and beliefs toward classroom management style? Paper presented at the annual conference of the Southwest Educational Research Association. Austin, Texas.

Marulis, L. M., Palincsar, A. S., Berhenke, A. L., \& Whitebread, D. (2016). Assessing metacognitive knowledge in 3-5 year olds: the development of a metacognitive knowledge interview (McKI). Metacognition and Learning, 11(3), 339-368. https://doi.org/10.1007/s11409-016-9157-7.

Ministry of National Education (2013). Okul öncesi eğitim programı [Early childhood education program]. Ministry of National Education.

Ministry of National Education (2014). Milli eğitim bakanlığı okul öncesi eğitim ve ilköğretim kurumları yönetmeliği [Ministry of national education regulations on pre-school and elementary education institutions]. Ministry of National Education.

Ministry of National Education (2019). Milli eğitim istatistikleri örgün eğitim, 2018-2019 [National education statistics: Formal education]. Ministry of National Education Strategy Development Presidency.

Meijer, J., Veenman, M. V. J., \& van Hout-Wolters, B. H. A. M. (2006). Metacognitive activities in textstudying and problem-solving: development of a taxonomy. Educational Research and Evaluation, 12(3), 209-237. https://doi. org/10.1080/13803610500479991 
Moos, D. C., \& Ringdal, A. (2012). Self-regulated learning in the classroom: A literature review on the teacher's role. Education Research International, 2012. https://doi.org/10.1155/2012/423284.

Muijs, D., Kyriakides, L., van der Werf, G., Creemers, B., Timperley, H. \& .Earl, L. (2014) State of the art - Teacher effectiveness and professional learning. School Effectiveness and School Improvement, 25(2) (2014), 231-256. https://doi.or $\mathrm{g} / 10.1080 / 09243453.2014 .885451$.

Neitzel, C., \& Connor, L. (2017). Messages from the milieu: Classroom instruction and context influences on elementary school students' self-regulated learning behaviors. Journal of Research in Childhood Education, 31(4), 548-560. https://doi. org/10.1080/02568543.2017.1347113.

Nelson, T. O., \& Narens, L. (1994). Why investigate metacognition? In J. Metcalfe \& A. P. Shimamura (Eds.), Metacognition: Knowing about Knowing (p. 1-25). The MIT Press.

Noonan, B. \& Duncan, C. (2005). Peer and selfassessment in high schools. Practical Assessment, Research, and Evaluation, 10(17). https://doi.org/10.7275/a166-vm41.

Panadero, E., \& Alonso-Tapia, J. (2013). Self-assessment: Theoretical and practical connotations. When it happens, how is it acquired and what to do to develop it in our students. Electronic Journal of Research in Educational Psychology, 11(2), 551576. https://doi.org/10.14204/ejrep.30.12200.

Panadero, E., Brown, G.T. \& Strijbos, J. (2016). The future of student aelf-Assessment: A review of known unknowns and potential directions. Educational Psychology, 28, 803-830. https://doi.org/10.1007/ s10648-015-9350-2.

Panadero, E., Jönsson, A. \& Botella, J. (2017). Effects of self-assessment on self-regulated learning and self-efficacy: Four meta-analyses. Educational Research Review, 22, 74 -98. https://doi. org/10.1016/j.edurev.2017.08.004.

Panadero, E. \& Romero, M. (2014). To rubric or not to rubric? The effects of self-assessment on selfregulation, performance and self-efficacy. Assessment in Education: Principles. Assessment in Education Principles Policy and Practice, 21(2), 133-148. https://doi.org/10.1080/096959 $4 \times .2013 .877872$

Paris, S. G., \& Paris, A. H. (2001). Classroom applications of research on self-regulated learning. Educational Psychologist, 36(2), 89-101. https:// doi.org/10.1207/S15326985EP3602_4.
Perels, F., Merget-Kullman, M., Wende, M., Schmitz, B. \& Buchbinder, C. (2008). Improving self-regulated learning of preschool children: Evaluation of training for kindergarten teachers. British Journal of Educational Psychology, 79(2), 311-27. https://doi.org/10.1348/000709908X322875.

Perels, F., \& Otto, B. (2009). Promoting self-regulated learning in preschool and primary school age. In F. Hellmich \& S. Wernke (Eds.), Learning Strategies in Primary School, 174-193. Stuttgart: Kohlhammer.

Perren, S., Herrmann, S., Iljuschin, I., Frei, D., Körner, C., \& Sticca, F. (2017). Child-centred educational practice in different early education settings: Associations with professionals' attitudes, selfefficacy, and professional background. Early Childhood Research Quarterly, 38(1), 137-148. https://doi.org/10.1016/j.ecresq.2016.07.001.

Perry, N. E. (1998). Young children's self-regulated learning and contexts that support it. Journal of Educational Psychology, 90(4), 715-729. https:// doi.org/10.1037/0022-0663.90.4.715.

Perry, N., Phillips, L. \& Dowler, J. (2004). Examining features of tasks and their potential to promote self-regulated learning. Teachers College Record, 106(9), 1854-1878. https://doi.org/10.1111/ j.1467-9620.2004.00408.x.

Perry, N. \& Vandekamp, K. (2000). Creating classroom contexts that support young children's development of self-regulated learning. International Journal of Educational Research, 33(7), 821-843. https://doi.org/10.1016/S08830355(00)00052-5.

Peeters, J., De Backer, F., Kindekens, A., Triquet, K., \& Lombaerts, K. (2016). Teacher differences in promoting students' self-regulated learning: Exploring the role of student characteristics. Learning and Individual Differences, 52, 88-96. https://doi.org/10.1016/j.lindif.2016.10.014.

Pintrich, P. (2000). The role of goal orientation in selfregulated learning. In M., Boekaerts, P., Pintrich, M., \& Zeidner (Eds.), Handbook of self-regulation, 451-502. Academic Press.

Pintrich, P., Wolters, C. \& Baxter, G. (2000). Assessing Metacognition and Self-regulated Learning. Published in G. Schraw \& J. C. Impara (Eds.), Issues in the Measurement of Metacognition. Buros Institute of Mental Measurements.

Pressley, M. (2000). What should comprehension instruction be the instruction of? In M. L. Kamil, P. B. Mosenthal, P. D. Pearson, \& R. Barr (Eds.), Handbook of Reading Research, Vol. 3, 545-561. Lawrence Erlbaum Associates Publishers. 
Robson, S. (2010). Self-regulation and metacognition in young children's self-initiated play and Reflective Dialogue. International Journal of Early Years Education,18(3), 227-241. https://doi.or $\mathrm{g} / 10.1080 / 09669760.2010 .521298$

Shamir, A., Mevarech, Z. R., \& Gida, C. (2009). The assessment of meta-cognition in different contexts: individualized vs. peer assisted learning. Metacognition and Learning, 4(1), 4761. https://doi.org/10.1007/s11409-008-9032-2.

Schraw, G. (1998). Promoting general metacognitive awareness. Instructional Science, 26(1), 113-125. https://doi.org/10.1023/A:1003044231033.

Schraw, G., Crippen, K. \& Hartley, K. (2006). Promoting self - regulation in science education: Metacognition as part of a broader perspective on learning. Research in Science Education, 36(1), 111-139. https://doi.org/10.1007/s11165-0053917-8.

Schraw, G., \& Moshman, D. (1995). Metacognitive theories. Educational Psychology Review, 7(4), 351-371. https://doi.org/10.1007/BF02212307.

Spruce, R., \& Bol, L. (2015) Teacher beliefs, knowledge, and practice of self-regulated learning. Metacognition and Learning, 10, 245-277. https:// doi.org/10.1007/s11409-014-9124-0.

Stipek, D., Feiler, R., Daniels, D., \& Milburn, S. (1995). Effects of different instructional approaches on young children's achievement and motivation. Child Development, 66(1), 209-223. https://doi. org/10.2307/1131201.

Tanriseven, I. (2013). Primary school teachers' realization levels of self-regulated learning practices and sense of efficacy. Educational Research and Reviews, 8(7), 297-301. https://doi.org/10.5897/ ERR2012.0493.

Tepe, D. ve Demir, K. (2012). Okul Öncesi Öğretmenlerinin Öz-Yeterlik İnançları Ölçeği. Abant izzet Baysal Üniversitesi Eğitim Fakültesi Dergisi, 12(2), 137-158.

Thomas, V., Peeters, J., De Backer, F., \& Lombaerts, K. (2020). Determinants of self-regulated learning practices in elementary education: a multilevel approach. Educational Studies, 1-23. https://doi. org/10.1080/03055698.2020.1745624.

Tschannen-Moran, M., Woolfolk Hoy, A.\&Hoy, W. K. (1998) Teacher efficacy: Its meaning and measure. Review of Educational Research, 68, 202-248. https://doi.org/10.3102/00346543068002202.
Vandevelde, S., Keer, H. \& Rosseel, Y. (2013). Measuring the complexity of upper primary school children's self-regulated learning: A multicomponent approach. Contemporary Educational Psychology, 38(4), 407-425. https:// doi.org/10.1016/j.cedpsych.2013.09.002.

Varol, F. (2013). What they believe and what they do, European Early Childhood Education Research Journal, 21(4), 541-552. https://doi.org/10.1080/13 $50293 \times .2012 .677309$

Veenman, M. V. J. (2005). The assessment of metacognitive skills: What can be learned from multi-method designs? In C. Artelt \& B. Moschner (Eds.), Lernstrategien und Metacognition: Implikationen für Forschung und Praxis, 77-99. Waxmann.

Venitz, L. \& Perels, F. (2019a). Promoting self-regulated learning of preschoolers through indirect intervention: a two-level approach. Early Child Development and Care, 2057-2070. https://doi. org/10.1080/03004430.2018.1434518.

Venitz, L., \& Perels, F. (2019b). The Promotion of Self-regulated Learning by Kindergarten Teachers. International Electronic Journal of Elementary Education, 11(5), 437-448. https://doi. org/10.26822/iejee.2019553340.

Whitebread, D. (2000). The psychology of teaching and learning in the primary school. RoutledgeFalmer.

Whitebread, D., Anderson, H., Coltman, P., Page, C., Pasternak, D. P., \& Mehta, S. (2005). Developing independent learning in the early years. Education 3-13, 33(1), 40-50. https://doi. org/10.1080/03004270585200081.

Whitebread, D., Bingham, S., Grau, V., Pasternak, D. P., \& Sangster, C. (2007). Development of metacognition and self-regulated learning in young children: Role of collaborative and peer-assisted learning. Journal of Cognitive Education and Psychology, 6(3), 433-455. https:// doi.org/10.1891/194589507787382043.

Whitebread, D., Bingham, S., Grau, V., Pino-Pasternak, D., and Sangster, C., Coltman, P., Almegdad, Q., \& Demetriou, D. (2009). The development of two observational tools for assessing metacognition and self-regulated learning in young children. Metacognition and Learning, 4(1), 63-85. https:// doi.org/10.1007/s11409-008-9033-1. 
Whitebread, D., \& Coltman, P. (2010). Aspects of pedagogy supporting metacognition and selfregulation in mathematical learning of young children: Evidence from an observational study. The International Journal on Mathematics Education, 42(2), 163-178. https://doi.org/10.1007/ s11858-009-0233-1

Wilcox-Herzog, A. (2002) Is there a link between teachers' beliefs and behaviors? Early Education and Development, 13(1), 81-106, doi:10.1207/ s15566935eed1301_5.

Winne, P. H. (1996). A metacognitive view of individual differences in self-regulated learning. Learning and Individual Differences, 8, 327-353. https:// doi.org/10.1016/S1041-6080(96)90022-9

Wolters, C. (2003) Regulation of motivation: evaluating an underemphasized aspect of self-regulated learning. Educational Psychologist, 38(4), 189205. https://doi.org/10.1207/S15326985EP3804_1

Zelazo, P. D. (2015). Executive function: Reflection, iterative reprocessing, complexity, and the developing brain. Developmental Review, 38, 55-68. https://doi.org/10.1016/j.dr.2015.07.001.

Zimmerman, B. J. (2008). Investigating self-regulation and motivation: Historical background, methodological developments, and future prospects. American Educational Research Journal, 45(1), 166-183. https://doi. org/10.3102\%2F0002831207312909.

Zimmerman, B.J., Bonner, S., \& Kovach, R. (1996). Developing self -regulated learners: Beyond achievement to self - efficacy. American Psychological Association.

Zimmerman, B. J., \& Schunk, D. H. (2011). Self-regulated learning and performance. In B. J. Zimmerman and D. H. Schunk (Eds.), Handbook of self regulation of learning and performance, 1-12. Routledge.

Zembat, R., \& Yilmaz, H. (2018). Examining The Relationship between Levels of Teaching Practices Preschool Teachers Use to Promote Children's Self-Regulated Learning and Their Self-Regulation Levels. In H. Arslan, R. Dorczak\& D. U. Alina-Andreea (Eds.) Educational Policy and Research, 521-529. Krakow: Monographs and Studies the Ellonian University - Institute of Public Affairs 